\title{
$\underline{\text { The place of research in teacher education }}$
}

Gillian Peiser

\section{Introduction}

This chapter explores (i) how different types of research are fundamental in informing programme content (research in teacher education) and (ii) how teacher education research is also useful in influencing programme design and structure (research on teacher education) (Cochran-Smith and Demers, 2008). The discussion of research in teacher education will present a rationale for research-rich teacher preparation and development and then review three different types of research: pedagogical content knowledge, professional enquiry, and innovative modes of integrating theory and practice. The analysis of research on teacher education will pay particular attention to the insights gleaned into how teachers learn, and illustrate how this knowledge has informed the content of teacher preparation courses. In addition to exploring the benefits and value of research in and on teacher education, the chapter will examine some of the associated challenges: the tensions between competence based teacher standards and a wider professional understanding, the contested nature of 'valid' educational research, issues related to teacher educators' research capacity, and the difficulties in developing an evidence base in teacher education.

The focus of this book is on teacher education across the UK and Ireland. This chapter focuses primarily on the four nations within the UK, although many of the points made have clear relevance to Ireland (and see also Chapter 8 by O'Doherty where the place of research in Irish teacher education is discussed), and indeed internationally. It begins with a brief overview of the policy context for teacher education research in each of the four jurisdictions of the UK. Those issues will then 
be readdressed in the discussion section with respect to the key points made in the chapter.

\section{Policy context}

The analysis by Beauchamp et al (2013) sees the contribution of research to teacher education as having broad institutional acceptance in Scotland, Wales and Northern Ireland, but as currently contested in England. England's position as an 'outlier', however, may be seen as a relatively recent development (Beauchamp et al, 2013), following the election of the Coalition Government in 2010.

Prior to that election, Hulme et al (2009) noted that all the teacher standards across the jurisdictions of the UK made reference to the fact that 'accomplished' teachers would need to draw on research to inform or improve professional practice. The New Labour government advocated that teaching should become a Master's profession (DCSF, 2008) and starting in 2002, various state funded 'applied' Master's degrees for in-service teachers were introduced: in Scotland, the Chartered Teacher Scheme (CT) (SEED, 2002); in England, the Masters in Teaching and Learning (MTL) (TDA, 2009); and in Wales, the Masters in Educational Practice (MEP) (GTCW and WG, 2012) (see Chapters 6, 4 and 7 respectively for more detailed accounts of these).

At a European level, the status of research had been bolstered by the Bologna agreement in 1999, which required all postgraduate qualifications in the European Union to be at Master's level. On postgraduate routes into teaching then, even in England, it often became an expectation that student teachers not only engage with educational research, but also conduct some empirical research on practice.

At the time of writing this chapter, the Scottish and Northern Irish Teacher Standards continue to make explicit references to the significance of research- 
informed practice. Although, in Wales, there is no reference to research in the Standards, its importance is highlighted in the non-statutory guidance documents that outline expectations for teacher education providers. The financial backing of the Welsh government for the MEP for newly qualified teachers was also indicative of political support for research-informed practice. When the Coalition Government came to power in 2010, funding for the MTL in England was withdrawn and the new English Teachers' Standards, introduced in 2012, make no explicit mention of the importance of research. These policy developments illustrate how government policy may promote or impede research-informed teacher education and how views about what should constitute teacher knowledge may be seen as inherently political.

\section{Research in teacher education}

\section{Why research-rich teacher education?}

In response to the 'diverging policy and provision for teacher education and heightened attention to the use of evidence and research', the British Educational Research Association (BERA) together with the Royal Society for the Arts (RSA) commissioned an inquiry into the 'Role of Research in Teacher Education’ (BERARSA, 2014a), in order to provide an evidence base for its importance. The BERARSA Report advocates teachers' 'research engagement', namely 'the involvement of teachers and school and college leaders in the doing of research’ (BERA, 2014b, p.40) and 'research literacy', that is that teachers should be 'familiar with a range of research methods, with the latest research findings and with the implications of this research for day-to-day practice, and for education policy and practice more broadly’ (BERA, 2014b, p.40). 
Within the Inquiry, one of the papers by Winch et al (2013) argues that research-rich content in teacher education is fundamental so that beginning and inservice teachers are able to draw on a wide body of collective knowledge, pooled from a variety of different perspectives. In their critique of teaching narrowly conceived as a 'craft', as in some prescriptions from the government in England (Gove, 2010), Winch and colleagues (2013, p.5) highlight the need to discriminate between common and good sense. They contend that the former is a 'conservative and potentially unreliable basis for professional judgement' and that 'good sense' decisions about teaching should be underpinned by reference points found in research.

As the final report of the Inquiry (BERA-RSA, 2014b) argues, researchinformed teacher education reaches further than promoting theoretical understanding in its own right. It advocates evidence-based instruction which makes a practical contribution to the lives of young people. Furthermore, 'research literacy' not only empowers teachers to become autonomous evaluators and improvers of their work, but can also enhance professional identity.

Macbeath (2011) has argued, along similar lines, that programmes which prioritise experiential learning in the work-place without reference to research not only undermine the body of wisdom that has grown on teaching, but fragment future knowledge, as new insights are more difficult to aggregate when learning is organised at the local level. Although experiential learning within the workplace is very important in helping teachers to develop their understanding of 'what works' in practice, learning from context alone can be limited as it ignores alternative (and potentially superior) approaches or solutions outside the immediate environment (Eraut, 2014). 
The importance of research based knowledge and research literacy to inform educational practice is clearly recognised in Finland and Singapore (Tatto, 2013), two countries that score highly in international attainment comparative analysis tests. In Finland, there is a very close relationship between schools where students learn to teach and the universities (Kansanen, 2014). Indeed, teacher education is based on the idea of teacher-as-researcher of their own professional practice. In Singapore, research informs the design, structure and content of its teacher education programme and there is a strong emphasis on academic and pedagogical knowledge based on national and international research (Tatto, 2013).

However, as Tatto (2013) also indicates, it is difficult to make a causal link between high attainment of pupils and a research base for teacher education and thus, the connection can only be inferred. Nonetheless, international and meta-studies would suggest that even if connections cannot be directly proven, they are often widely assumed in the literature on teacher education. For example, the OECD (2012) has claimed that in order to address the needs of lower achievers and in so doing, raise educational attainment, teachers will require a wide pedagogical repertoire that meets the individual needs of students coupled with expertise in supporting students' metacognitive processes. As Mincu (2013, p.4) identifies, it is very difficult to see how teachers can acquire such a repertoire without research-based teacher education.

\section{Diversification of research in teacher education}

Over the years, research-informed teacher education has developed in different directions. In the Anglophone world, there has been a shift away from the study of the sub-disciplines of the study of education (for example sociology, psychology and 
history of education) to more pragmatic and applied forms of knowledge that seek to make a practical contribution (Furlong, 2013). A particular focus for research informed content in teacher education has been on pedagogical content knowledge (PCK) (Shulman 1986), that is, the knowledge base of teaching that rests at the intersection of subject content and pedagogy, and the powerful influence of its application on student learning (for example: Chiesa and Robertson (2000) study about 'precision methods' in mathematics and Graham and Macaro’s (2008) research on explicit strategies for teaching listening in foreign languages). Teacher education informed by research into PCK is of great significance given that Seidel and Shavelson’s (2007) meta-study on the impact of different factors on student knowledge building uncovered that domain-specific learning, that is how students develop and learn in specific subject areas, has the greatest effect size on student progress.

Whilst a great deal of attention continues to be paid to research on PCK and effective teaching and learning strategies to inform 'evidence-based' practice, there has been some diversification away from a 'process-product approach', that is the 'processes' that were considered reliable in achieving desired goals or 'products' (Hagger and McIntyre 2000, pp. 485-6). Teacher educationalists have problematised the concept that certain processes inevitably lead to desired goals due to the complexities of diverse educational settings and the particularity of beliefs and practices of individual teachers (Stuart and Tatto, 2000). In light of this knowledge, research in teacher education has had to become relevant to the context in which student teachers find themselves and take account of teachers' beliefs and values.

\section{Practitioner enquiry and teacher research}


Rather than focusing entirely on theory or research generated by others, practitioner enquiry is concerned with developing research skills in order to inform and develop practice and promotes active learning in context (Hardy and Rönnerman, 2011), where teaching is conceptualised as a 'problem to be solved' (Dickson 2011, p.269). The purpose of practitioner enquiry is to generate knowledge for practice from practice, where the professional context acts as the site for enquiry (Cochran-Smith and Lytle, 2009). In this way, ownership and production of research shifts from the 'ivory tower of academe' to teachers or student teachers within their own contexts, who seek new insights into the processes of teaching and learning, effectively bridging the theory-practice divide (Burton et al, 2014). That is not to say that those who conduct practitioner enquiry do not engage with more substantive research from external sources or a larger knowledge base. Indeed, rigorous practitioner, or action research, is a cyclical process which systematically investigates the application of aspects from a wider knowledge base in a particular context. Cochran-Smith and Lytle (2009, p.94) present it as a hybrid of conceptual research and empirical research, enabling teachers to make decisions based on evidence.

Practitioner enquiry not only helps teachers to engage in and with research that is contextually applicable, but potentially has more far reaching benefits. As Ross and Bruce (2012) established, teachers who conduct action research reported improved confidence in their professional abilities. Similarly, Dickson (2011) and Truxaw et al (2011) found that practitioner enquiry helped student teachers to develop their professional identity and perceptions of self-efficacy. Although teacher confidence cannot be directly equated with impact on student learning, in her systematic review of the impact of work-based professional learning, Cordingley (2013, p.1) established that enquiry-orientated learning and a focus on refining teaching and learning 
'working towards aspirations for specific pupils side by side with theory’ were key characteristics of effective continuing professional development (CPD). Similarly, Mincu (2013, p.10) claims that teachers who engage in on-site collaborative enquiry processes 'make a vital contribution to ensuring effective teaching and learning processes are in place and in building capacity for whole school improvement'. These studies demonstrate how teacher research may serve different purposes, ranging from the professional development of the individual to school improvement.

Whilst action research is a typical form of practitioner enquiry, teacher research can may take on a multiplicity of forms. As Baumfield et al (2013) note, teacher research commonly involves a process of investigating questions which arise directly from classroom experience and can therefore fall in a middle ground between reflection and action research. It is debatable whether reflective practice is a form of research in itself. For example, Richardson, 1994 claims that Schön's (1983) notion of 'reflection-in-action' and its potential to improve practice has often been referred to as teacher research, whereas, Burton et al, 2014, p.150 argue that 'so-called evidence' generated from reflective practice is 'often anecdotal and derived from ad hoc experiences’. Nevertheless reflective practice is frequently drawn on in teacher education as a gateway to research. Taking its origins in the work of Dewey (1933), and particularly influenced by the work of Schön (1983; 1987), various typologies of reflective practice have been created for the teaching profession (for example, Calderhead and Gates, 1993; Moon, 2004; Pollard and Collins, 2005). These approaches prompt teachers to consider the goals and values that guide their work, how their own biographies may influence practice (Brookfield, 2002) and the critical exploration of the perspectives of different stakeholders in the workplace. On several teacher education courses (for both pre- and in-service teachers), the examination of 
alternative perspectives through reflective practice is used to scaffold critical engagement with research and theory. For example, the Masters in Teaching degree developed by the London Institute of Education continually involved students 'in a [conversational] discourse about their own learning and that of their peers [which then made] reference to relevant conceptual and theoretical frameworks' (Daly et al, 2007, p.104).

\section{Innovative ways for integrating theory and practice}

Some teacher educators (for example, Griffiths and Tann, 1992; Korthagen and Kessels, 1999) have reconceptualised the importance of theory with a 'big T', arguing that beginning teachers are likely to find this too abstract and difficult to make sense of and indeed, that taking this conservative view of theory may even contribute to further polarising of theory and practice. Korthagen and Kessels (1999) propose that attention should firstly be paid to theory with a 'small T', namely the exploration of students’ personal and subjective reflections on teaching practice. It is only after personal theories are worked through that these should be linked with theoretical notions from a wider and more abstract knowledge base. In this way, learning to teach is based on the on a constructivist notion that it is a subject to be created rather than a 'ready-made’ subject (Korthagen et al, 2006).

Whilst reflective practice in different guises has gained widespread popularity as a 'research springboard', the Oxford Internship Scheme (McIntyre, 1990), first developed in the 1980s, rejects 'more elaborated notions of experiential learning that emphasise 'reflective practice', in which it is experience alone that constitutes the focus for reflection' (Burn and Mutton, 2013, p.2). Instead, the Oxford programme is designed to enable the integration of experiential learning and research-based 
knowledge, where school and university knowledge are interrogated in the light of each other, based on a model of 'research-informed clinical practice' (Burn and Mutton, 2013) and promoting ‘practical theorising’ (McIntyre, 1995). On this programme, beginning teachers are trained and supported to adopt research-informed practice rather than imitating experienced teachers or proceeding through trial and error. The purpose of this process is to enable the important 'interplay between the different kinds of knowledge that are generated and validated within the different contexts of school and university’ (Burn and Mutton, 2013, p.1). The Oxford Internship Scheme presents teaching 'as a process of hypothesis-testing, requiring interpretation and judgement in action, rather than routinised application of learned repertoires' (Burn and Mutton, 2013, p.4). Similar 'research-informed clinical practice' schemes have been promoted and developed in Scotland, the U.S., Australia, the Netherlands and Finland. For example, the University of Glasgow developed a clinical practice scheme which involved the co-operative working of university tutors and school mentors in a cluster of volunteer schools with sustained presence of university staff (Conroy et al, 2013). Together, university tutors, school mentors and student teachers were engaged in collaborative enquiry into authentic pedagogical problems. A full discussion of other schemes involving these and similar examples of research-informed clinical practice can be found in the review by Burn and Mutton (2013).

\section{Issues and challenges for research in teacher education}

As it has become apparent, the research element within and across teacher education programmes can take on a variety of forms. Within the confines of this chapter, we have drawn attention to an applied form of research (PCK), an evaluative form of 
research (practitioner enquiry) and innovative ways of integrating theory and practice, although there are several others. Within the university context, diversification of research types has led to deliberation about the most suitable content for teacher education programmes. There is debate amongst academics about whether to foreground the focus on more substantive forms of research, such as how children learn and subject knowledge, or to concentrate on PCK, practitioner research skills or scholarship of reflective practice (Stuart and Tatto, 2000). There are also questions about the most appropriate times in a teacher's development for these foci and how they should be integrated with experiential learning (ibid). As Furlong (2013) notes, the field of education has had difficulties in establishing itself as a 'discipline' due to the diversity of areas with which it is concerned. Whilst such variety can be considered as healthy as it enables programmes to 'evolve, change, and develop out of the local context and in response to the perceived needs of the time and place' (Stuart and Tatto, 2000, p.511), in some quarters this can lead to uncertainties about which type of research to foreground, especially if theoretical approaches are questioned by policy makers and the time afforded to research-informed elements is restricted.

Indeed, HEIs across the UK face considerable tensions between supporting their students to meet teachers' standards or competences, a pre-requisite for qualified teacher status, which are demonstrated in practice, and developing a professional understanding linked to wider perspectives (see Chapter 9). These difficulties are further compounded when, as in England, only a third of postgraduate course time is spent in the university. As Beauchamp et al (2013) note though, even on such courses, most university ITE provision has continued to combine perspectives from 
educational research with meeting the imperatives of making programmes practical and relevant, making use of practitioner enquiry or action research modes of learning.

however, even when research in teacher education is used to provide helpful explanations or a theoretical underpinning for defined standards (Hagger and McIntyre 2000) and universities organise research informed teaching in this way, there is potential to focus on educational research that marries with the current political agenda and by consequence, to dismiss alternative perspectives. In fact, what counts as 'valid' educational research in and for teacher education is part of a larger and highly contested issue.

For example, since 2010 the Department for Education in England (DfE) has been lending high levels of support to quasi-experimental research through their investment in randomised controlled trials (RCTs). The purpose of the RCTs is to establish which teaching strategies are most likely to deliver the best results for 'closing the gap' between the educational attainment of young people from contrasting socio-economic backgrounds (DfE, 2013). The DfE, however, is less enthusiastic about other types of research that may contribute to educational understanding, as is evident in the ex-Secretary of State for Education, Michael Gove's, critique of the ‘ideologically driven theory’ (Gove, 2013) promoted by schools of education in universities.

Across all universities in the UK, the Research Excellence Framework (REF) also influences what counts as 'good' research. The REF assesses the quality of research to inform allocation of research funding in UK HEIs 'in terms of originality, significance and rigour' (REF, 2014) and to provide research benchmarking information. In funding terms, the emphasis is upon research which is internationally 
excellent. Small-scale, practitioner-orientated research, which may well have limited international excellence or impact, is simply unable to compete with more 'scientific' types of research within this framework and is thus less likely to receive acclaim and recognition. So whilst practitioner-orientated enquiry is promoted within teacher education programmes for the sake of professional development, teacher educator professionalism and improvements in teacher education, it is less likely to be recognised as 'high quality' by a wider audience within the university sector.

The ramifications of the REF can also impact negatively on research capacity building in university schools of education (Christie et al, 2012). The fact that there are winners and losers of research funding has been recognised to affect the ways in which teacher educators engage in scholarship (Jones et al, 2011). Where funds are absent, this may hinder or even sever links between teaching and research, denying opportunities for teacher educators to undertake research as an essential part of their professional development (Murray et al, 2008).

As the BERA-RSA final report (2014b) underlines, research-informed teaching may be less prevalent if the teacher educators and mentors teaching on ITE programmes lack research experience. Teacher educators in the UK tend to be former school teachers, who by consequence of their career routes, have often not acquired research expertise before arrival to university posts (Harrison and McKeon, 2008). The constant pressure to develop programmes that are highly practically orientated means that many universities are more interested in recruiting staff with 'professional rather than academic capital' (Furlong, 2013, p.143) and that some universities are less likely to develop or invest in the academic profiles of their staff when neither government directives or inspection frameworks pay tribute to research (Furlong, 2013). According to Menter et al (2010), only one third of staff working as academics 
in departments or faculties of education in the UK were returned research active in the Research Assessment Exercise in 2008 (the predecessor to the REF). There may therefore be a gulf between educational research and those who 'mobilise' or teach this knowledge, as highlighted by Nelson and O’Beirne (2014, p.36), when they call for more and better brokerage between the producers and users of research through a centrally coordinated 'knowledge mobilisation infrastructure'.

The next section of the chapter illustrates how the type of research promoted in teacher education has been strongly influenced by research on teacher education, in particular in the area of how teachers learn and develop knowledge. We will see that research on teacher education also faces challenges, particularly in providing answers to policy questions about which modes of preparation are likely to 'create' the most effective teachers.

\section{Research on teacher education}

Research on teacher education is of interest to both policy makers and teacher educators. Policy makers are concerned with finding evidence for justifying a particular model of teacher preparation at the macro level and therefore seek out research which is able to establish cause-effect relationships between pre-service training and teacher effectiveness (measured in terms of pupil attainment). However, research of this nature is very difficult to conduct and as yet, is still to provide clear cut findings about such relationships. 
One of the major reasons for this lies with issues of methodology. Most research on teacher education in the UK has adopted interpretive or practitioner enquiry genres (Menter et al, 2010) and is thus similar to the type of research conducted in teacher education. Commenting from a U.S. perspective, Borko et al (2007, p.8) also note the predominance of these approaches and explain their popularity by saying that they 'lend themselves to study the teaching and/or learning processes, a topic of deep interest to most teacher educators; in addition, studies within these genres often can be conducted by individual scholars and without external funding.' Whilst this type of research has been helpfully applied at the micro level of teacher education to inform curriculum development, the challenge of aggregation has resulted is the absence of a coherent knowledge-base that can be used to inform larger policy decisions (Tatto, 2000; Borko et al, 2007; Murray et al, 2008; Menter et al, 2010).

Research on teacher education has tended to focus on understanding how teachers develop and acquire knowledge, and has explored the diversity of experiences in learning to teach. This body of knowledge has contributed to programme design and has been very influential on the types of research discussed earlier in the chapter.

\section{How teachers learn and develop knowledge and the impact on programme design}

Since the 1970s, there has been extensive research that has revealed the centrality of teachers' lives, beliefs and values in their practice and development. We know from this work (for example Ball \& Goodson, 1985; Goodson, 1991; Hagger and McIntyre, 
2000; MacLure, 2001) that teachers’ professional choices and actions frequently reflect the negotiation of their identities and values within structural parameters and that these are likely to vary in strength at different stages of their careers, depending on the strength of these factors. In light of this knowledge, teacher education has looked to support student teachers in their exploration of professional identities and sense of mission, providing them with opportunities to ask themselves not only what they and others consider to be important, but also to reflect on whether their actions mirror their beliefs (Korthagen, 2004). Teacher education programmes also seek to engage beginning teachers in developing a vision for teaching, or set of images, of ‘the possible’ (Feiman-Nemser, 2001 in Hammerness et al, 2005, p.386). Whilst some beginning teachers need help in actualising an already identified teacher identity, others require support in undergoing a 'transformation of self in the endeavour of change into a teacher' (Hobson et al, 2005, p.132).

The proliferation of reflective practice orientated programmes, supported by conceptual models and 'reflective tools' such as critical incident analysis (see Tripp, 1994) and narrative enquiry for the purpose of professional development (Conle, 2000), can also be viewed as a response to research on how teacher biography may shape teacher behaviour. These approaches not only enable support tailored to individuals but also provide frameworks for navigating the emotionally charged experiences which we know are commonly encountered by beginning teachers (Hobson et al, 2005, 2006).

Parallel to the findings on the centrality of teachers as individuals, enquiry into teachers’ professional learning has established the powerful impact of the social and 
cultural contexts in which knowledge is acquired and used (Feiman- Nemser, 2008; Timperley, 2008). As learning to become a teacher has been increasingly recognised as an active and constructive process in a 'community of practice' (Lave and Wenger, 1991), teacher education courses have supplemented their focus on knowledge for practice with attention to the development of knowledge in practice and of practice (Cochran-Smith and Lytle, 1999). Programmes have paid attention to the need for learning tasks within the practicum to be carefully graduated and the importance of allocated time for collaboration and dialogue with colleagues, mentors and expert teachers. When conditions allow for the latter, beginning teachers are not only able to reflect on their own practice, but also access expert teachers' articulation of their decision-making, 'making their tacit craft knowledge explicit' (Burn and Mutton, 2013, p.2).

In order to take full advantage of learning within a community of practice, teacher education has stressed the importance of creation of knowledge of practice (Cochran-Smith and Lytle, 1999), which is generated when classrooms and schools are treated as sites for enquiry and practice is evaluated and interpreted in light of larger social, cultural and political issues and the theory and research of others. In creating this practice-theory loop, theoretical study in teacher education maintains its relevance as it is explicitly linked to teachers' work (Korthagen et al, 2006; Hobson et al, 2006).

In addition to the study of teacher individuality and the impact of social and contextual factors on how teachers learn, scholars have also examined the nature of teacher expertise. The development of expertise has frequently been conceptualised in light of stage theories, whereby teachers progress over a period of time (of usually 
five to seven years) from being concerned with themselves, and learning the basic elements of the task, to gradually becoming more aware of issues related to students and student learning and developing the ability to respond appropriately in a variety of different situations (Berliner, 1994). Studies have established that more expert teachers also engage more frequently in meta-cognition (see Hammerness et al, 2002 in Hammerness et al, 2005). In view of this, programmes scaffold learning so that novice teachers can progress through the stages more rapidly and develop strong levels of metacognitive competence earlier than might otherwise be expected (Hammerness et al, 2005).

Research on teacher education has thus provided much knowledge that has helped to inform programme design. It has highlighted how teacher education must recognise that teachers themselves are the 'central actors' in their own development (Hagger and McIntyre, 2000), the necessity of creating courses that best support professional learning within a community of practice, and the need to scaffold learning in such a way that enables teachers progress to the expert stage as early as possible.

\section{Challenges in establishing an evidence-base for teacher education}

Whilst the body of research discussed earlier has revealed much about how teachers learn and has helped to inform programme design at a micro level, it has, as indicated previously, been less successful in ascertaining the relative effectiveness and outcomes of different models of teacher education (Tatto, 2013). As Menter et al (2010) established in their study of teacher education research in the UK, there is a 
distinct absence of research on teacher education that adopts experimental methods of enquiry that supports the evidence-based education movement. Although there have been some exceptions to this general picture; for example the TEDS-M study conducted by Tatto et al (2012), which established that top-performing countries relied on university-based teacher education with a strong emphasis on subject content, pedagogical content knowledge and carefully constructed links between theory and practice, a well-developed research infrastructure for studying the impact of particular practices in teacher preparation has yet to be established.

Cochran-Smith (2005) explains that many of the problems here are related to the fact that there are difficulties in building a chain of evidence that links (a) teacher education and student learning, (b) student learning and their practices in the classroom and finally, (c) practices of the teacher and how much their students learn. However, Cochran-Smith (2002, p.285) also argues in an earlier publication that questions about how to best prepare teachers can never be answered on the basis of research evidence alone as such questions 'also have to do with ideas, ideals, values, and beliefs about teaching and learning [...] and the purposes of education in a democratic society'. In spite of this philosophical argument and the difficulties in establishing a chain of evidence, Borko et al (2007) argue that the investigation of these relationships should now constitute the research agenda. They call for larger and more complex studies which draw upon multiple methods and take advantage of new technologies for processing and analysing larger data sets.

Grossman and McDonald (2008) point out, however, that many problems lie within the newness of the field, claiming that in comparison to research on teaching, which is now an 'adult' discipline, research on teacher education is still in its 
'adolescence'. They stress the need to establish common conceptual frameworks with a common language with a universally recognised vocabulary in order to enable greater precision for describing and analysing teaching. Their views on language are concordant with those of Korthagen et al (2006), who suggest that the development of a shared professional language among teacher educators and researchers is a prerequisite for developing a knowledge base on which to build teacher education practices in different settings and countries.

Indeed, Korthagen and colleagues (2006) conducted a meta-study in three different countries in order to establish common principles that underpin effective teacher education. Their work investigated the factors that best enable programmes to be responsive to the expectations, needs and practices of teacher educators and student teachers. From their findings, they established seven principles for student teacher learning and programme change in teacher education. They surmised that learning about teaching:

- involves continuously conflicting and competing demands;

- requires a view of knowledge as a subject to be created rather than as a created subject;

- requires a shift in focus from the curriculum to the learner;

- is enhanced through (student) teacher research;

- requires an emphasis on those learning to teach working closely with their peers;

- requires meaningful relationships between schools, universities and student teachers;

- is enhanced when the teaching and learning approaches advocated in the programme are modelled by the teacher educators in their own practice.

Whilst such principles offer a helpful conceptual framework for future research, the teacher education community still has some way to go in developing a multimethods and multi-disciplinary research infrastructure with theoretical tools that are able to address the critical questions asked by policy makers. 


\section{Discussion}

Research in teacher education then is able to greatly enhance course content in providing a wide professional knowledge base, assisting beginning and experienced teachers in making critically informed judgements and contributing to the development of broad pedagogical repertoires. The development of 'research literacy' (BERA-RSA, 2014b) enables teachers to enquire into and improve their own practice and can help to develop professional identity. The significant contribution of research rich content and research literacy in teacher education is clearly recognised in the top performing countries in educational attainment in the world (Tatto, 2013).

In spite of these compelling arguments, there are practical challenges in making research a high status aspect of teacher education. The principle constraints in the UK are imposed when policy prioritises instrumental knowledge over a wider professional understanding. In Scotland and Northern Ireland, where there is a more collaborative and co-operative approach between universities and policy makers to teacher education, there are relatively strong commitments to research-rich teacher initial teacher education (ITE). In England, however, the absence of reference to research in the Teachers' Standards, and a policy drive to shift teacher preparation away from university-led programmes to more school-based programmes, renders the status of research less stable. Whilst, from a positive perspective, there is policy support for research within teaching schools’ alliances, whereby R\&D constitutes one of the 'big six' responsibilities of teaching schools (NCTL, 2014), and the promotion of evidence-based practice based on the results from RCTs (DfE, 2013), there are reasons to be concerned about the fragmentation of research knowledge in teacher education and the sidelining of the wide-ranging types of research that contribute to teacher understanding. 
Although there is a commitment to research-rich pre-service teacher education in Scotland and Northern Ireland, the BERA-RSA Inquiry (2014b) highlighted issues related to research orientated continuing professional development (CPD). In Scotland, the Inquiry revealed that teachers' experiences of CPD, and their engagement with research within this, are disjointed. Similarly, whilst there are clear references to reflective practice and research engagement expressed in the General Teaching Council for Northern Ireland's Code of Values and Professional Practice and Teacher Competence Framework, these have not yet been widely developed beyond initial teacher education (BERA-RSA, 2014b). Thus, there is work to be done in Scotland and Northern Ireland in making research engagement and literacy characteristics of teachers’ lifelong learning.

Policy embodied in changing curriculum frameworks and 'quality assurance’ measures also pose challenges to the prominence of research within teacher education in the UK. As Furlong (2013) has highlighted, constantly changing national curricula for schools, revisions of teachers' standards and accountability measures which interfere with the detail of teacher education, create uncertainty within the teacher education community about what professional knowledge is and what research elements contribute to this. Accountability measures in England, where the outcomes of rigorous inspection procedures of ITE (which pay little concern to research activity) impact on the allocation of resources, may render research-rich teacher education and research building capacity as a lesser priority for some schools of education.

All four nations, however, are affected by the necessity to deliver high quality taught programmes which affect the way in which tutors are deployed. A report by the OECD (2014, p.73) uncovered that in Wales most staff 'were consumed with teaching responsibilities, leaving them with no flexibility to accommodate research’. The 2015 
report on ITE in Wales by John Furlong focused very directly on the dearth of educational research in the institutions with responsibility for pre-service teacher education (Furlong, 2015). Even in universities which invest in research excellence to raise prestige and reputation and to improve funding levels through the REF, there can be a 'dual economy of teaching and research and a corresponding dual labour market' (Menter et al, 2010, p.122). Leitch (2009, p.355) noted that in Northern Ireland, where there is 'a climate of openness between policy-maker and researcher communities', the Research Assessment Exercise (the predecessor to the REF) has created a gulf between research-active and 'not research-active' staff (p.358). Similarly, the Department of Education and Skills in the Republic of Ireland (2012) noted a lack of critical mass for research purposes and in fact, recommended the merging of providers in order to enhance research building capacity.

\section{Conclusion}

The chapter has demonstrated how both research in and on teacher education has much to offer those in the business of teacher preparation but that both types face a variety of challenges. Research rich teacher education, in its variety of forms, ultimately supports teachers in making judicious decisions based on wide professional knowledge that are likely to contribute to improved outcomes for young people. The diversification of research has resulted in a compromise between theory and practice, with both a commitment to theoretical aspects of knowledge and to the desire to make a practical contribution to the field. Although the status of research in teacher education in the UK is strongly influenced by regional politics, unresolved questions about the precise nature of teacher knowledge amongst the academic 
community, and barriers in the way of research capacity-building, make research-rich teacher education more vulnerable in the face of political scepticism about its value.

Whilst the teacher education community has studied how teachers learn and develop (research on teacher education), and this has been helpful in informing programme design, there is an urgent need to research different modes of teacher education at the macro level, so that the sensible rationale for research-informed education can be further interrogated in light of empirical evidence.

This issue is particularly pertinent in a policy context where there is an emerging plethora of different preparation routes. Drawing on a domestic and international evidence base, the BERA-RSA Inquiry has started the ball rolling here. However, if the so-called 'adolescent field' of teacher education is to grow up quickly and find its adult voice, investment is required in large scale, longitudinal studies so that teacher preparation policy is informed by reliable data sets rather than politics and ideology.

But research of this nature requires substantial financial backing of a funding body which will need convincing of the research rationale, aims and strategy for this work, no mean feat in a period in a period of economic austerity. In critical times, however, where teacher education has become a political football, these challenges need confronting head-on.

\section{$\underline{\text { References }}$}

Ball, S. J., \& Goodson, I. F. (eds) (2002) Teachers' lives and careers, East Sussex: The Falmer Press.

Baumfield, V., Hall, E. \& Wall, K. (2013).Action Research in Education (2nd edn), London: SAGE. 
Beauchamp, B., Clarke, L., Hulme, M. \& Murray, J. (2013) Policy and practice within the United Kingdom. Research and teacher education: The BERARSA Enquiry. Retrieved from http://www.bera.ac.uk/wpcontent/uploads/2013/12/BERA-Paper-1-UK-Policy-and-Practice.pdf

Berliner, D. (1994) 'Teacher expertise', Teaching and learning in the secondary school, 107-113.

BERA-RSA (2014a) The role of research in teacher education. Reviewing the evidence. Interim report of the BERA-RSA Inquiry, Author: London. Retrieved from http://www.bera.ac.uk/wp-content/uploads/2014/02/BERA-RSAInterim-Report.pdf

BERA-RSA (2014b) Research and the teaching profession. Building the capacity for a self-improving education system. Final report of the BERA-RSA Inquiry into the role of research in teacher education, Author: London. Retrieved from https://www.bera.ac.uk/wp-content/uploads/2013/12/BERA-RSA-ResearchTeaching-Profession-FULL-REPORT-for-web.pdf

Borko, H., Liston, D., \& Whitcomb, J. A. (2007) ‘Genres of empirical research in teacher education', Journal of Teacher Education, 58(1): 3-11.

Brookfield, S. D. (2002) 'Using the lenses of critically reflective teaching in the community college classroom', New Directions for Community Colleges, 118: 3138.

Burn, K. \& Mutton, T. (2013) Review of 'research-informed clinical practice' in initial teacher education. Research and teacher education: The BERA-RSA Inquiry. Retrieved from http://www.bera.ac.uk/wp-content/uploads/2014/02/BERA-Paper-4$\underline{\text { Research-informed-clinical-practice.pdf }}$ 
Burton, N., Brundrett, M., \& Jones, M. (2014) Doing your education research project, London: Sage.

Calderhead, J. \& Gates, P. (eds) (2003) Conceptualising reflection in teacher development, London: The Falmer Press.

Chiesa, M. \& Robertson, A. (2000) 'Precision teaching and fluency training: Making maths easier for pupils and teachers', Educational Psychology in Practice 16(3): 297-310.

Christie, D., Donoghue, M., Kirk, G., McNamara, O., Menter, I., Moss, G., ... \& Whitty, G. (2012) Prospects for education research in education departments in higher education institutions in the UK. UCET/BERA Report. Retrieved from: http://www. bera. ac. uk/publications/bera-ucet-report.

Conle, C. (2000) 'Narrative enquiry: Research tool and medium for professional development', European Journal of Teacher Education, 23(1): 49-63.

Cochran-Smith, M. (2002) 'Reporting on teacher quality: The politics of politics’ Journal of Teacher Education, 53(5): 379-382.

Cochran-Smith, M. (2005) 'Studying Teacher Education What We Know and Need to Know', Journal of Teacher Education, 56(4): 301-306.

Cochran-Smith, M., \& Demers, K. E. (2008) 'How do we know what we know? Research and teacher education’ in: Cochran-Smith, M. et al (eds) Handbook of research on teacher education: Enduring questions in changing contexts, NY: Routledge, pp 1009-1016.

Cochran-Smith, M., \& Lytle, S. L. (2009) Enquiry as stance: Practitioner research for the next generation, NY: Teachers College Press.

Conroy, J., Hulme, M, \& Menter, I. (2013) ‘Developing a ‘clinical’ model 
for teacher education', Journal of Education for Teaching: International research and pedagogy, 39(5): 557-573.

Cordingley, P. (2013) The contribution of research to teachers' professional learning and development. Research and teacher education: The BERA-RSA Enquiry. Retrieved from http://www.bera.ac.uk/wp-content/uploads/2013/12/BERA-Paper-5Continuing-professional-development-and-learning.pdf

Daly, C., Pachler, N., \& Lambert, D. (2004) 'Teacher learning: towards a professional academy', Teaching in Higher Education, 9(1): 99-111.

DCSF (2008) Being the best for our children. Green Paper, London: DCSF.

Dewey, J. (1933) How we think, Boston: D. C. Heath.

Department of Education and Skills (2012) Report of the International Review Panel on the Structure of Initial Teacher Education Provision in Ireland, Dublin: Author. Retrieved from http://www.education.ie/en/Press-Events/PressReleases/2012-Press-Releases/Report-of-the-International-Review-Panel-on-the$\underline{\text { Structure-of-Initial-Teacher-Education-Provision-in-Ireland.pdf }}$

DfE (2013) New randomised controlled trials will drive forward evidencebased research. Retrieved from: https://www.gov.uk/government/news/new$\underline{\text { randomised-controlled-trials-will-drive-forward-evidence-based-research }}$

Dickson, B. (2011) 'Beginning teachers as enquirers: m-level work in initial teacher education’, European Journal of Teacher Education, 34(3): 259-276.

Eraut, M. (2014) ‘Developing knowledge for qualified professionals’ in O. McNamara, Murray, J.and Jones, M. (eds) (2014) Workplace Learning in Teacher Education. Professional Learning and Development in Schools and Higher Education Volume 10, Dordrecht: Springer, pp 47-72. 
Feiman-Nemser, S. (2008) 'Teacher learning: How do teachers learn to teach' in: Cochran-Smith, M. et al (eds) Handbook of research on teacher education: Enduring questions in changing contexts, NY: Routledge, pp 697-705.

Furlong, J. (2013). Education - an anatomy of the discipline. Rescuing the university project? Oxon: Routledge.

General Teaching Council of Northern Ireland (2007) Teaching: The Reflective Profession, Belfast: GTCNI. Retrieved from http://www.gtcni.org.uk/uploads/docs/gtcni_comp_bmrk\%20\%20aug\%2007.pdf

General Teaching Council for Wales and Welsh Government [GTCW and WG] (2012) Induction, Masters in Educational Practice (MEP) and Early Professional Development (EPD): Funding, tracking and recording arrangements, Cardiff: GTCW / WG.

Gleeson, J. et al (2013) Understanding the role and potential for research capacity-building in initial teacher education (ITE) programmes in the North and South of Ireland: A baseline and comparative study. Report published by the Centre for Cross Border Studies for The Standing Conference on Teacher Education North and South (SCoTENS). Retrieved from http://scotens.org/2013/10/new-researchreport-launched-at-scotens-annual-conference/

Goodson, I. F. (1991) 'Sponsoring the teacher's voice: Teachers' lives and teacher development', Cambridge Journal of Education, 21(1): 35-45.

Gove, M. (2013) I refuse to surrender to the Marxist teachers hell-bent on destroying our schools, The Daily Mail. 23 March 2013. Retrieved from http://www.dailymail.co.uk/debate/article-2298146/I-refuse-surrender-Marxistteachers-hell-bent-destroying-schools-Education-Secretary-berates-new-enemiespromise-opposing-plans.html 
Graham, S. \& Macaro, E. (2008) 'Strategy Instruction in Listening for Lower - Intermediate Learners of French', Language learning, 58(4): 747-783.

Griffiths, M. \& Tann, S. (1992) 'Using reflective practice to link personal and public theories’, British Journal of Teacher Education, 18(1): 69-84.

Grossman, P. \& McDonald, M. (2008) 'Back to the future: Directions for research in teaching and teacher education', American Educational Research Journal, 45(1): 184-205.

Hagger, H., \& McIntyre, D. (2000) 'What can research tell us about teacher education?, Oxford Review of Education, 26(3-4): 483-494.

Hammerness, K et al (2005) ‘How teachers learn and develop’ in: DarlingHammond, L. \& Bransford, J. (eds) Preparing teachers for a changing world: What teachers should learn and be able to do, San Francisco: Jossey-Bass, pp 358-389.

Hardy, I., \& Rönnerman, K. (2011) 'The value and valuing of continuing professional development: current dilemmas, future directions and the case for action research’ Cambridge journal of education, 41(4): 461-472.

Harrison, J., \& McKeon, F. (2008) 'The formal and situated learning of beginning teacher educators in England: identifying characteristics for successful induction in the transition from workplace in schools to workplace in higher education', European journal of teacher education, 31(2): 151-168.

Hobson, A., \& Malderez, A. (2005) Becoming a Teacher: Student teachers' motives and preconceptions, and early school-based experiences during initial teacher training (ITT), Nottingham: The University of Nottingham.

Hobson, A.et al (2006). Becoming a teacher: Student teachers' experiences of initial teacher training in England, Nottingham: The University of Nottingham. 
Hulme, M., Baumfield, V., \& Payne, F. (2009) 'Building capacity through teacher enquiry: the Scottish Schools of Ambition', Journal of Education for Teaching, 35(4): 409-424.

Jones, M., et al (2011) 'Facilitating teacher educators' professional learning through a regional research capacity-building network', Asia-Pacific Journal of Teacher Education, 39(3): 263-275.

Kansansen, P. (2014) Teaching as a Master’s Level Profession in Finland: Theoretical Reflections and Practical Solutions, 279-392 in in O. McNamara, Murray, J.and Jones, M. (eds) (2014) Workplace Learning in Teacher Education. Professional Learning and Development in Schools and Higher Education Volume 10, Dordrecht: Springer, pp 47-72.

Korthagen, F. A. (2004) 'In search of the essence of a good teacher: Towards a more holistic approach in teacher education', Teaching and teacher education, 20(1): 77-97.

Korthagen, F. et al (2006) 'Developing fundamental principles for teacher education programs and practices', Teaching and teacher education, 22(8): 10201041.

Lave, J., \& Wenger, E. (1991). Situated learning: Legitimate peripheral participation, Cambridge: Cambridge university press.

Leitch, R. (2009) 'Harnessing the slipstream: building educational research capacity in Northern Ireland. Size matters.' Journal of Education for Teaching 35(4 ): 355-371.

MacBeath, J. (2011) 'Education of teachers: The English experience’, Journal of Education for Teaching, 37(4): 377-386. 
MacLure, M. (2001) ‘Arguing for yourself: Identity as an organising principle in teachers' jobs and lives' in J. Soler et al (eds) Teacher development exploring our own practice, London: Sage, pp 167-180.

McIntyre, D. (1990) ‘The Oxford Internship Scheme and the Cambridge Analytical Framework: models of partnership in initial teacher education’ Partnership in initial teacher training, 110-127.

McIntyre, D. (1995) 'Initial Teacher Education as Practical Theorising: A Response to Paul Hirst', British Journal of Educational Studies, 365-383.

Menter I. et al (2010) 'Teacher education research in the UK: the state of the art', Schweizerische Zeitschrift für Bildungswissenschaften, 1(32): 121-142.

Mincu, M. (2013). Teacher quality and school improvement. Research and teacher education: The BERA-RSA Inquiry. Retrieved from http://www.bera.ac.uk/wp-content/uploads/2013/12/BERA-Paper-6-Teacher-Qualityand-School-Improvement.pdf

Moon, J. A. (2004) A handbook of reflective and experiential learning: Theory and practice, Hove: Psychology Press.

Murray, J. et al (2009) 'Research and teacher education in the UK: Building capacity’, Teaching and Teacher Education, 25(7): 944-950.

Nelson, J. \& O’Beirne (2014) Using Evidence in the Classroom: What Works and Why? Slough: NFER.

NCTL (2014) Teaching schools: national research and development network. Retrieved from https://www.gov.uk/the-national-research-and-development-network

OECD (2012) Equity and quality in education. Supporting disadvantaged students and schools, Paris: author. Retrieved from http://dx.doi.org/10.1787/9789264130852-en 
OECD (2014) Improving Schools in Wales: An OECD Perspective, Paris : author. Retrieved from http://www.oecd.org/edu/Improving-schools-in-Wales.pdf REF (2014) http://www.ref.ac.uk/

Pollard, A. \& Collins, J. (2005) Reflective teaching, London: Bloomsbury Publishing.

Ross, J. A., \& Bruce, C. D. (2012) 'Evaluating the impact of collaborative action research on teachers: a quantitative approach', Teacher Development, 16(4): 537-561.

Schön, D. A. (1983) The reflective practitioner: How professionals think in action (Vol. 5126), NY: Basic books.

Schön, D. A. (1987) Educating the reflective practitioner: Toward a new design for teaching and learning in the professions, San Francisco: Wiley.

SEED (2002) Standard for Chartered Teacher, Edinburgh: Scottish Executive Education Department.

Seidel, T., \& Shavelson, R. J. (2007) 'Teaching effectiveness research in the past decade: The role of theory and research design in disentangling meta-analysis results', Review of educational research, 77(4): 454-499.

Shulman, L. S. (1986) 'Those who understand: Knowledge growth in teaching', Educational researcher, 4-14.

Stuart, J. S., \& Tatto, M. T. (2000) ‘Designs for initial teacher preparation programs: an international view', International Journal of Educational Research, 33(5): 493-514.

Tatto, M. T. et al (2012) Policy, Practice, and Readiness to Teach Primary and Secondary Mathematics in 17 Countries: Findings from the IEA Teacher 
Education and Development Study in Mathematics (TEDS-MM), Amsterdam: International Association for the Evaluation of Educational Achievement.

Tatto, M. T. (2013) The role of research in international policy and practice in teacher education. The BERA-RSA Inquiry. Retrieved from http://www.bera.ac.uk/wp-content/uploads/2014/02/BERA-Paper-2-International$\underline{\text { Policy-and-Practice-in-Teacher-Education.pdf }}$

Timperley, H. (2008) Teacher Professional Learning and Development. Educational Practices Series-18, Geneva: UNESCO International Bureau of Education.

TDA (2009) The national framework for masters in teaching and learning, London: TDA.

Tripp, D. (1994) 'Teachers’ lives, critical incidents, and professional practice’ Qualitative Studies in Education, 7(1): 65-76.

Truxaw, M. P. et al (2011) 'A Stance toward Enquiry: An Investigation of Preservice Teachers' Confidence regarding Educational Enquiry’, Teacher Education Quarterly, 38(4): 69-95.

Winch, C. et al (2013) The Contribution of Educational Research to Teachers' Professional Learning - Philosophical Understandings. The BERA-RSA Inquiry. Retrieved from http://www.bera.ac.uk/wp-content/uploads/2014/02/BERA-Paper-3$\underline{\text { Philosophical-reflections.pdf }}$ 
